\title{
Environmental Factors Influencing Gardner Saltbush Seed Dormancy Alleviation
}

\author{
R. JAMES ANSLEY AND ROLLIN H. ABERNETHY
}

\begin{abstract}
Pregermination treatments applied to seed of Gardner saltbush, [A triplex gardneri (Moq.) D. Dietr.] were evaluated for alleviation of seed dormancy. Treatments selected simulated conditions the seed might be exposed to in its natural environment, including dry afterripening, scariflcation, leaching, and cold stratification. Germination response to individual treatments was equal to or higher than nontreated seed. Germination percentage of afterripened seed was increased from $17 \%$ for nontreated filled seed to an average of $86 \%$ of filled seed by the combined treatments of scarification, leaching, and 4-week stratification. This combination of treatments allowed optimum germination. Response to treatments provided evidence as to the type of dormancy in Gardner saltbush seeds. The levels of germination response to specific treatments appears to be an adaptation to ensure a temporal dispersal of dormancy release and seedling emergence. Pregermination treatments used in this study were relatively easy to apply to the seeds and stimulated germination without potentially damaging the embryo. Thus, they would be useful in revegetation by direct seeding efforts.
\end{abstract}

Gardner saltbush [Atriplex gardneri (Moq.) D. Dietr.] is a lowgrowing perennial half-shrub, 20 to $50 \mathrm{~cm}$ tall, which occurs in cold desert regions of Montana and Wyoming. It is particularly adapted to saline, alkaline, and clayey soil conditions, extreme temperatures, high winds, and aridity (Stubbendieck et al. 1981). It is a

Authors are postdoctoral research associate, Texas A \& $M$ Agricultural Experiment Station, Vernon 76348; and assistant professor, Plant Science Division, University of Wyoming, Laramie 82071 . At the time of the research, the senior author was a graduate research assistant, Plant Science Division, University of Wyoming.

Research was funded in part by the University of Wyoming Agricultural Exp. Sta. and the High Plains Grassland Res. Sta., through USDA-ARS Coop. Agreement No. 58: 9 A HZ-9-467. Published as Wyoming Agricultural Exp. Sta. Journal Article 1286. Manuscript accepted October 1, 1984 valuable winter forage and aids in stabilization in areas where grasses are not predominant.

Seed dormancy can be considerable in Gardner saltbush and closely related Atriplex spp. (Foiles 1974, Vories 1981), and this may explain why previous efforts to establish these species via direct seeding have largely been unsuccessful (Bleak et al. 1965, Nord et al. 1971, McKell 1979). Beadle (1952), Twitchell (1955), Cornelius and Hylton (1969), and others found that the presence of salts in the utricle imposed dormancy in seeds of many Atriplex spp. and that leaching with water partially alleviated dormancy. Most of these species, unlike Gardner saltbush, occur in Mediterranean climates and dormancy breaking mechanisms may be somewhat different (Chatterton and McKell 1969, Osmond et al. 1980). Atriplex spp. occurring in colder climates, including Gardner saltbush, reportedly have cold stratification requirements ranging from 2 weeks to 10 months at 2 to $5^{\circ} \mathrm{C}$ (McLean $1953^{1}$, Foiles 1974, Eddleman 19782). It is not known whether stratification affects embryo or seedcoat dormancy in Atriplex spp. A better understanding of processes involved in alleviation of Gardner saltbush seed dormancy may aid future revegetation efforts.

In some species a correlation exists between requirements for dormancy alleviation and conditions necessary for seedling establishment (Mayer and Poljakoff-Mayber 1975, Thompson 1973). We hypothesized that because Gardner saltbush evolved in an extremely variable desert environment which offers infrequent opportunities for successful seedling establishment, maximum

'McLean, A. 1953. The autecology of Atriplex nuttalli S. Wats. in southwestern Saskatchewan. M.S. Thesis, Utah State Agr. Coll., Logan.

${ }^{2}$ Eddleman, L.E. 1978. Survey of viability of indigenous grasses, forbs, and shrubs. Annu. Prog. Rep. prepared for U.S. Energy Res. and Devel. Admin. Missoula, Mont., p 160-161. 
dormancy alleviation and subsequent germination involves complex interactions of many environmental factors on physiological processes within the seed.

The objective of this study was to simulate conditions in the natural environment which might alleviate Gardner saltbush seed dormancy and determine their interactive effects on dormancy release. Additional objectives were to characterize dormancy as to type and characterize the ecology of dormancy removal for this species, based on germination response to simulated environmental seed treatments.

\section{Materials and Methods}

\section{Seed Procurement}

Gardner saltbush seeds were collected August 1 through 7, 1980 and 1981 from 3 distinct populations (Knobs, Rasmussen, and Red Desert) of 4 ha or less located from 15 to $70 \mathrm{~km}$ west of Rawlins $\left(41^{\circ} 40^{\prime}\right.$ to $41^{\circ} 50^{\prime} \mathrm{N}$ latitude, $107^{\circ} 27^{\prime}$ to $108^{\circ} 06^{\prime} \mathrm{W}$ longitude) in the Red Desert Basin of South Central Wyoming. The populations were named after local landmarks. The elevation ranges from 2,033 $\mathrm{m}$ to $2,036 \mathrm{~m}$ and average annual precipitation from 15 to $18 \mathrm{~cm}$ at all 3 sites. Mean monthly maximum and minimum temperatures during May and June range from 19 to $26^{\circ} \mathrm{C}$, and 4 to $7^{\circ} \mathrm{C}$, respectively (Becker and Alyea 1964).

Seeds were collected by hand stripping. Freshly harvested seeds were spread on a canvas tarp to air dry. Stems and leaves were removed via screening. Dust, chaff, and broken seed parts were removed using an adjustable pneumatic separator containing seed collection baffles in a vertical plexiglass column (Young et al. 1978). Seed was stored in paper bags at 20 to $24^{\circ} \mathrm{C}$ for dry afterripening before application of additional pregermination treatments (Springfield 1970, Foiles 1974).

\section{Seed Fill and Viability}

The female Gardner saltbush flower has no perianth, protection being provided by 2 bracteoles 3 to $6 \mathrm{~mm}$ long which form a false fruit or utricle (Young et al. 1980). In this study the utricle was considered the seed. Seed fill and viability were determined by slicing 15 replicates of 100 utricles and by soaking bisected embryos ( 5 replicates, each containing 25 embryos) in a $0.1 \%$, 2,3,5-triphenyl-2H-tetrazolium chloride (TZ) solution for 4 to 8 hours (Grabe 1970, Weber and Wiesner 1980).

\section{Seed Pregermination Treatments}

Seed pregermination treatments were applied following afterripening $\left(20\right.$ to $22^{\circ} \mathrm{C}$ ) for 2,5 , and 15 months post-harvest. Treatments included 2 levels of scarification, 3 levels of leaching, and 3 levels of cold stratification arranged in a 2 by 3 by 3 completely randomized factorial. Seeds occupying a volume of $250 \mathrm{~cm}^{3}$ were scarified for 20 seconds in a carborundum-lined drum (3 liters in volume) containing a motorized steel rotary propeller rotating at $1725 \mathrm{RPM}$. The leaching treatments included $200 \mathrm{~cm}^{3}$ of seeds in a $600 \mathrm{ml}$ beaker covered with cheesecloth and exposed to $6^{\circ} \mathrm{C}$ running tap water (flow rate: 35 to $40 \mathrm{ml} / \mathrm{sec}$ ) for either 1 or 24 hours. Leached seeds were then air dried $\left(21^{\circ} \mathrm{C}\right)$ for 24 hours to facilitate handling. Cold stratification involved maintaining imbibed seeds at $2^{\circ} \mathrm{C}$ for 2 or 4 weeks. Seeds were transferred directly to the germinator while in the imbibed condition following stratification. For combination treatments (i.e., scarification + leaching, scarification + stratification, leaching + stratification, scarification + leaching + stratification) seeds were initially scarified, then leached, air dried $\left(21^{\circ} \mathrm{C}\right)$ for 24 hours to facilitate handling, and finally rehydrated for the stratification treatment.

Treatments were replicated 6 times using 100 seeds per replication. Seeds in each replication were contained on 1 sheet germination blotter moistened with $10 \mathrm{ml}$ distilled water in a 10 by 10 by 2.5 $\mathrm{cm}$ plastic tray with tightly fitting lid, and incubated at a 16 hour, 22 to $24^{\circ} \mathrm{C}$-light (cool white fluorescent, 1.1. $\mathrm{W} \mathrm{m}^{-2}$ )/ 8 hour, 10 to $13^{\circ} \mathrm{C}$-dark daily cycle. Germination, assessed by $15-\mathrm{mm}$ radicle extension, was counted at 5-day intervals for 40 days. No fungicides or other seed protectants were used during the study.

\section{Seed Leachate Study}

Ten grams each of unscarified and scarified seed from the Red Desert 1981 collection were soaked 2 hours in $60 \mathrm{ml}$ distilled water. Leachates were then decanted and diluted with distilled water to a constant volume of $100 \mathrm{ml}$. Each leachate was applied to both scarified and nonscarified sced that had been leached 24 hours and stratified 3 weeks. Treatments consisted of $100 \%, 50 \%$, and $25 \%$ leachate (diluted with distilled water) and a distilled water control. Each treatment was replicated 6 times. Each replication consisted of a glass, 9-cm, petri-dish and lid containing 50 seeds on 2 layers Whatman No. 2 filter paper and $6 \mathrm{ml}$ of the leachate treatment. Petri dishes were enclosed in plastic zip-lock bags to prevent evaporation of water from the dishes. Seeds were germinated for 2 weeks under the same incubation conditions as previously described.

An analysis of variance was conducted on data from all laboratory studies. Means were separated using the LSD test at $P \leq 0.05$.

\section{Results}

\section{Seed Fill and Viability}

Seed fill from all sources ranged from 48 to $64 \%$ of total seed (Table 1). Ninety percent or more of the embryos of filled seed from Table 1. Percent fill and viability of Gardner saltbush seeds collected in
the Red Desert Basin of Wyoming.

\begin{tabular}{lccc}
\hline \hline $\begin{array}{c}\text { Seed source/ } \\
\text { collection year }\end{array}$ & $\begin{array}{c}\text { Fill of } \\
\text { total seed }\end{array}$ & $\begin{array}{c}\text { Viability of } \\
\text { filled seed }\end{array}$ & $\begin{array}{c}\text { Viability } \\
\text { total seed }\end{array}$ \\
\hline & & $\%$ & \\
Knobs 1980 & 60 & 90 & 54 \\
Knobs 1981 & 62 & 94 & 58 \\
Rasmussen 1980 & 64 & 95 & 61 \\
Red Desert 1981 & 48 & 94 & 45 \\
\hline LSD.05 & 4.1 & 6.9 &
\end{tabular}

As determined by tetrazolium test.

each source were classified as viable by the TZ test, although staining in most of the embryos was nonuniform with portions (i.e., radicle, hypocotyl, cotyled ons) being either dark red, pink, or unstained. Only those embryos completely unstained were classified as nonviable.

\section{Effects of Pregermination Treatments on Cumulative Percent Germination \\ Afterripening}

No differences in cumulative percent germination of filled seed were obtained between 2 and 5 months post-harvest when the simple effect of afterripening was combined over all treatments, and combined over all wash and stratification treatments in both unscarified and scarified Knobs 1980 seeds (Table 2). A significant $(P \leq 0.05)$ increase was obtained at 15 months post-harvest, indicating some degree of afterripening occurred. When seeds were leached and stratified, germination of 15 month post-harvest seeds over both 2 and 5 month post-harvest seeds was further increased at all treatment levels (Fig. 1).

\section{Scarification}

Scarification in the absence of leaching or stratification increased germination of 2 month post-harvest seed by $18 \%$ and 5 month post-harvest seed by $22 \%$, over non-treated seed, but did not affect 15 month post-harvest seed (Fig. 1). Apparently, scarification as a single treatment was only effective in seeds that had not afterripened. In all cases effects of leaching and stratification were not as great in unscarified seed as they were in scarified seed. Thus, 

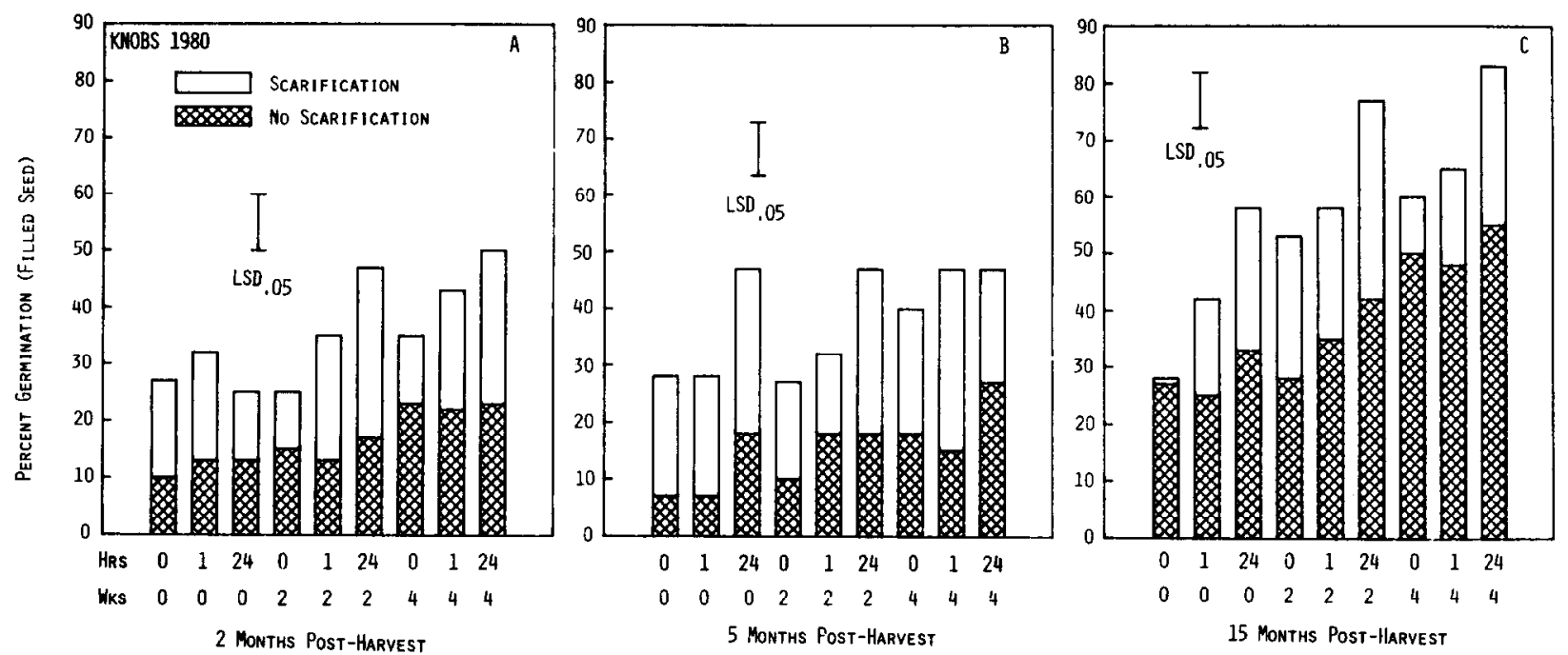

Fig. 1. Effects of afterripening (months post-harvest) on germination response of Knobs 1980 Gardner saltbush seeds to scarification, leaching, and cold stratification. Labels on X-axis are 0. 1, or 24 hours leaching (top row). and 0, 2, or 4 weeks cold stratification (bottom row). Means within a post-harvest date are separated by LSD at $\mathrm{P} \leq 0.05$.

Table 2. Effect of dry storage afterripening time on germination of Knobs (1980) Gardner saltbush seed.

\begin{tabular}{cccc}
\hline \hline & \multicolumn{3}{c}{$\begin{array}{c}\text { Cumulative percent germination } \\
\text { (of filled seed) }\end{array}$} \\
\cline { 2 - 4 } $\begin{array}{c}\text { Months post- } \\
\text { harvest dry } \\
\text { afterripening }\end{array}$ & $\begin{array}{c}\text { Means of } \\
\text { all } \\
\text { treatments }\end{array}$ & $\begin{array}{c}\text { Means of } \\
\text { unscarified } \\
\text { treatments }\end{array}$ & $\begin{array}{c}\text { Means of } \\
\text { scarified } \\
\text { treatments }\end{array}$ \\
\hline 2 & 26 & 17 & 35 \\
5 & 27 & 15 & 38 \\
15 & 48 & 38 & 58 \\
\hline LSD .06 & 9.8 & 7.7 & 11.7 \\
\hline
\end{tabular}

scarification appeared to enhance the sensitivity of the seeds to leaching and stratification.

\section{Leaching}

One-hour and 24-hour leaching treatments were not effective on unscarified 2 month post-harvest seeds (Fig. 1A). Leaching scarified seed significantly $(P \leq 0.05)$ increased germination over the unscarified control but these increases were no greater than those of scarification as a single treatment. Similar to the 2 month post-harvest seed, 1-hour and 24-hour leaching had no effect on unscarified 15 month post-harvest seed (Fig. 1C). One hour and especially 24 hours leaching significantly $(P \leq 0.05)$ increased germination of seeds that had been scarified prior to leaching.

In general, increasing concentrations of leachate from unscarified and scarified seed reduced germination of unscarified and scarified seeds that had been leached prior to leachate application, although some exceptions were apparent (Fig. 2).

\section{Stratification}

Four weeks stratification enhanced germination in unscarified 2 and 5 months post-harvest seed by $15 \%$ and $11 \%$, respectively, but 2 weeks stratification was not effective (Fig. 1A and IB). In scarified 2 and 5 months post-harvest seed, stratification as a single treatment was not effective at either level. By 15 months postharvest, 2 and 4 weeks stratification significantly $(P \leq 0.05)$ increased germination over the control, although 2 weeks stratification was only effective on scarified seeds. The effects of 4 weeks stratification appeared to be independent of scarification (Fig. 1C). Combined Pregermination Treatments

Maximum germination of 2 and 5 month post-harvest Knobs 1980 seed was obtained using a combination of scarification + leaching + stratification. However, only $50 \%$ of filled seed germinated at either of these post-harvest dates (Fig. IA and 1B). By 15 months post-harvest, 24 hours leaching +4 weeks stratification of scarified seed virtually removed dormancy, yielding $83 \%$ germination of filled seed (Fig. 1C). Interestingly, within this afterripening and scarification treatment, 24 hours leaching without 4 weeks stratification provided nearly the same germination $(58 \%)$ as 4 weeks stratification without leaching (60\%).

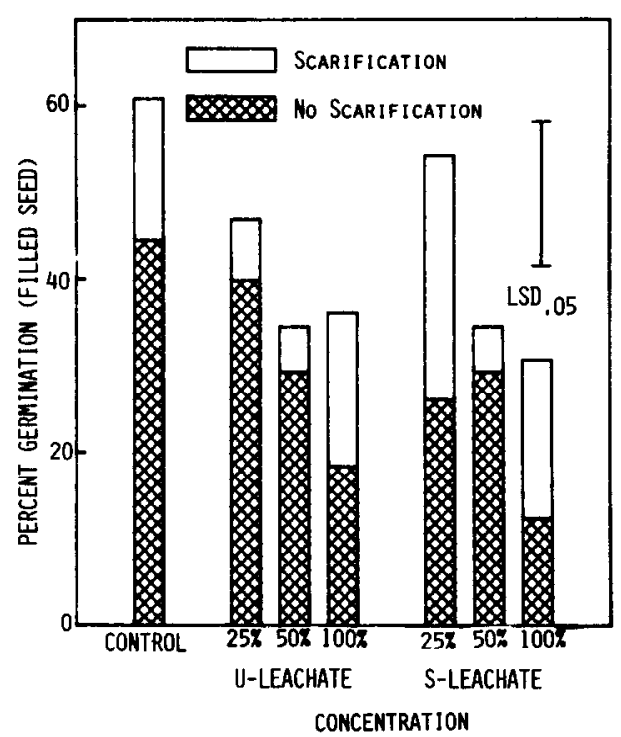

Fig. 2. Effects of leachates from unscarified $(U)$ and scarified $(S)$ seeds on germination of unscarified and scarified seeds. Leachates were applied to seeds at $25 \%, 50 \%$, and full concentration. Seeds in the control were imbibed in distilled water.

\section{Effect of Collection Year and Seed Source}

Fifteen month post-harvest seed collected from the Knobs site in 1981 showed response to pregermination treatments similar to 15 month post-harvest Knobs 1980 seed (Fig. 1C and 3). Scarification +24 hours leaching +4 weeks stratification yielded the greatest germination in seeds collected from both years. Response to 4 weeks stratification as a single treatment was less relative to other pregermination treatments in 1981 seed than 1980 seed. 
Rasmussen 1980 seed had the highest seed fill and viability of all seed collections in this study (Table 1). Germination response of 15 month post-harvest Rasmussen seed to pretreatments was generally higher than 15 month post-harvest Knobs 1980 and 1981 seed. Rasmussen seed showed a greater sensitivity to scarification than Knobs seed. Scarification alone increased germination by $28 \%$ in Rasmussen seed but only by $1 \%$ and $8 \%$ in Knobs 1980 and Knobs 1981 seed, respectively (Fig. 1C and Fig. 3). Moreover, effects of 1 hour and 24 hours leaching on unscarified seed were greater in Rasmussen than Knobs seed.
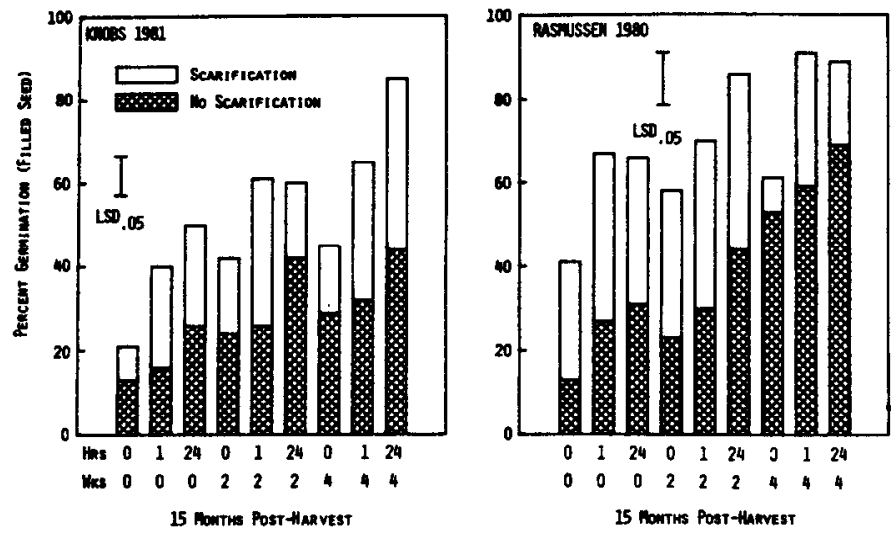

Fig. 3. Effects of scarification, leaching, and cold statification on germination of 15 months post-harvest Knobs 1981 and Rasmussen 1980 Gardner saltbush seeds. Labels on X-axis are 0, 1 , or 24 hours leaching (top row), and 0, 2, or 4 weeks cold stratification. Means within a population source are separated by $L S D$ at $\mathrm{P} \leq 0.05$.

\section{Interactive Effects of Seed Treatments}

Two or three factors (treatments) often must interact to release seeds from dormancy (Richards 1941, Popay and Roberts 1970). Combined factors may be additive in their effects (Vincent and Roberts 1977, Zagorski and Lewak 1983). Results from this study demonstrated that high seed germination in Gardner saltbush requires a complex interaction of at least $\mathbf{4}$ factors: afterripening, scarification, leaching, and cold stratification. Afterripening and scarification should be considered as requisite treatments for complete alleviation of dormancy since, without them, the effects of leaching and stratification were much reduced. Roberts and Smith (1977) and Nikolaeva (1969) found afterripening did not itself completely remove dormancy but enhanced the sensitivity of seeds to other dormancy breaking treatments such as stratification, alternating temperatures, and light. Nikolaeva (1969) noted that afterripening reduced the requirement for length of stratification in seeds of some hardwood species. This effect was not observed in Gardner saltbush during this study except in scarified seeds from the 1980 collections.

Seed collected from each of the 3 sources responded similarly to the treatments, although the Rasmussen collection provided a greater germination increase when scarified and when leached than the Knobs 1980 and 1981 collections. The significance of this is unknown. Soil characteristics of the sites differed in that Rasmussen had higher sodium absorption ratios and lower organic matter content than the Knobs site (Ansley 19833).

\section{Physiological Characterization of Dormancy}

It is impossible to directly determine whether embryo dormancy is present in a seed unless germination response in the absence of all other tissues is observed (Bewley and Black 1982). In Gardner saltbush seeds, the utricle is so tightly fused around the embryo

\footnotetext{
${ }^{3}$ Ansley, R.J. 1983. Dormancy, germination, emergence and ecology of Gardner saltbush [Atriplex gardneri (Moq.) D. Dietr.] seeds. Ph.D. Dissertation, Univ. Wyoming, Laramie.
}

that complete separation of the two usually results in damage to the embryo. Germination responses obtained from seed treatments imposed in this study therefore provide only indirect information for characterization of dormancy.

Evidence from this study suggests that seed dormancy in Gardner saltbush is both embryo and seed coat related. While scarification as a single treatment nearly always promoted germination, it did not completely remove dormancy in any collection, suggesting that dormancy is partially, but not entirely seed coatimposed. Stratification, a treatment commonly required by seeds of woody species which have embryo dormancy (Lewak and Rudnicki 1977, Bewley and Black 1982), was effective in removing dormancy. However, scarification appeared to reduce the requirement for length of stratification in the 15 month post-harvest 1980 collections, suggesting a seed coat influence. The inhibitory effect of leachate from unscarified seed on Gardner saltbush germination agrees with Cornelius and Hylton (1969), who reported a germination decrease from 14 to $4 \%$ (total seed) in desert saltbush [Atriplex polycarpa (Torr.) S. Wats.] when leachate of unscarified seed was reapplied to the seeds. The leachate concentration used in that study was similar to the undiluted concentration in this study. Leachate from unscarified seed may have contained inhibitors located in the utricle while leachate from scarified seed, which was much darker in color, implying a greater content of organic compounds, may have contained a higher percentage of inhibitors from the embryo.

\section{Ecology of Seed Dormancy Removal in Gardner Saltbush}

This study showed that seed dormancy in Gardner saltbush was removed in varying degrees by exposure to different simulated environmental pregermination treatments. This suggests that when the seed population is exposed to a particular environmental factor, only a portion of the population may have dormancy terminated and subsequently germinate. Bewley and Black (1982) noted this sporadic release from dormancy may be to the advantage of the species because it temporally disperses germination. This is important for species, such as Gardner saltbush, which occur in environments where conditions amenable to seedling survival occur infrequently.

While sporadic germination response to environmental stimuli may be the more frequent behavior in Gardner saltbush seeds, the potential for the entire population of viable seeds to germinate at a single time exists. Environmental conditions would have to include afterripening, utricle scarification, leaching, and cold stratification. The adaptive advantage of stratification and leaching may be to maximize germination in early spring when moisture and temperature conditions are most favorable for seedling growth. The requirement for afterripening and scarification may be necessary to provide an interval of time for spatial dispersal of the seed from the mother plant, and/or to prevent precocious germination.

\section{Research Implications: Gardner Saltbush Revegetation}

A better understanding of the processes involved in alleviation of seed dormancy may provide for greater success in establishing this species via direct seeding. This could be accomplished by artificially removing dormancy with pregermination treatments prior to seeding, or by increasing the accuracy of predicting emergence based on initial seeding rates.

A subsequent phase of this research involved an evaluation of field emergence of seed subjected to the pregermination treatments developed here. The results of that work appear elsewhere (Ansley and Abernethy 1984).

\section{References}

Ansley, R.J., and R.H. Abernethy. 1984. Seed pretreatments and their effects on field establishment of spring seeded Gardner saltbush. J. Range Manage. 37:509-513 
Beadle, N.C.W.1952. Studies in halophytes. 1. The germination of the seed and establishment of the seed lings of five species of Atriplex in Australia. Ecology. 33:39-62.

Becker, C.F., and J.D. Alyea. 1964. Temperature probabilities in Wyoming. Univ. Wyoming Agr. Exp. Sta. Bull. 415.

Bewley, J.D., and M. Black. 1982. Physiology and biochemistry of seeds. Vol. 2. Viability, dormancy, and environmental control. SpringerVerlag, New York.

Bleak, A.T., N.C. Frischknecht, A.P. Plummer, and R.E. Eckert. 1965. Problems in artificial and natural revegetation of the arid shadscale vegetation zone of Utah and Nevada. J. Range Manage. 18:59-63.

Chatterton, N.J., and C.M. McKell. 1969. Atriplex polycarpa: I. Germination and growth as affected by sodium chloride in water cultures. Agron. J. $61: 448-450$.

Cornelius, D.R., and L.O. Hylton. 1969. Influence of temperature and leachate on germination of Atriplex polycarpa. Agron. J. 61:209-211.

Foiles, M.W. 1974. Atriplex L., Saltbush. p. 240-243. In: C.S. Schopmeyer (ed.). Seeds of woody plants in the U.S. USDA Agr. Handb. 450, Washington, D.C.

Grabe, D.F. 1970. Tetrazolium testing handbook for agricultural seeds. Contrib. No. 29 to Handbook Seed Testing. Tetrazolium Test Comm. of the Ass. of Off. Seed Anal.

Lewak, S., and R.M. Rudnicki. 1977. Afterripening in cold-requiring seeds. p. 193-217. In: A.A. Khan (ed.). The Physiology and Biochemistry of Seed Dormancy and Germination. Elservier/North-Holland Biomedical Press.

Mayer, A.M., and A. Poljakoff-Mayber. 1975. The germination of secds. 2nd ed. Pergamon Press, New York.

McKell, C.M. 1979. Selection, propagation and field establishment of native plant species on disturbed arid lands. Utah Agr. Exp. Sta. Bull. 500 , Utah State Univ., Logan, Utah.

Nikolaeva, M.G. 1969. Physiology of deep dormancy in seeds. Leningrad: Izdakel'stvo “Nauka”, Isr. Prog. Sci. Transl., Jerusalem.

Nord, E.C., P.F. Hartless, and W.D. Nettle. 1971. Effects of several factors on saltbush establishment in California. J. Range Manage. 24:216-223.
Osmond, C.B., O. Bjorkman, and D.J. Anderson. 1980. p. 155-190. In: Physiological processes in plant ecology toward a synthesis with Atriplex. Springer-Verlag, New York.

Popay, A.I., and E.H. Roberts. 1970. Ecology of Capsella bursapastoris (L.) Medik and Senecio vulgaris L. In relation to germination behavior. J. Ecol. 58:123-139.

Richards, F.J. 1941. The diagrammatic representation of the results of physiological and other experiments designed factorially. Ann. Bot. (London) 5:249-261.

Roberts, E.H., and R.D. Smith. 1977. Dormancy and the pentose phosphate pathway. p. 384-411. In: A.A. Khan (ed.). The Physiology and Biochemistry of Seed Dormancy and Germination. Elsevier/NorthHolland Biomedical Press, Amsterdam.

Springfield, H.W. 1970. Germination and establishment of fourwing saltbush in the Southwest. USDA Forest Serv. Res. Paper RM-55, Rocky Mtn. Forest Range Exp. Sta., Ft. Collins, Colo.

Stubbendieck, J., S.L. Hatch, and K.J. Kjar. 1981. North American Range Plants. Nat. Res. Enterprises, Inc., Lincoln, Neb.

Thompson, P.A. 1973. Gcographical adaptation of seeds. p. 31-58. In: W. Heydecker (ed.). Seed Ecol. Butterworths, London.

Twitchell, L.T. 1955. Germination of fourwing saltbush as affected by soaking and chloride removal. J. Range Manage. 8:218-220.

Vincent, E.M., and E.H. Roberts. 1977. The interaction of light, nitrate and alternating temperature in promoting the germination of dormant seeds of common weed species. Seed Sci. Tech. 5:659-670.

Vories, K. 1981. Growing Colorado plants from seed: A state of the art. Vol. 1: Shrubs. USDA Forest Serv. Gen. Tech. Rep. INT-103. Intermtn. Forest Range Exp. Sta., Ogden, Utah.

Weber, G.P., and L.E. Wiesner. 1980. Tetrazolium testing procedures for native shrubs and forbs. J. Seed Tech. 5:23-34.

Young, J.A., B.L. Kay, H. George, and R.A. Evans. 1980. Germination of three species of Atriplex. Agron. J. 72:705-709.

Young, J.A., R.A. Evans, B.L. Kay, R.E. Owen, and F.L. Jurak. 1978. Collecting processing and germinating seeds of western wildland plants. USDA Sci. and Educ. Admin. Agr. Rev, and Manuals. ARM-W-3, Berkeley, Calif.

Zagorski, S., and S. Lewak. 1983. Interactions between hydrogen cyanide, gibberellin, abscisic acid and red light in germination of lettuce seeds. Physiol. Plant 59:95-98.

MOVING? Please try to give us four weeks notice. Send your present address label and this form to Society for Range Management 2760 W. 5th Ave. Denver, Colo. 80204

\author{
ATTACH OLD \\ ADDRESS LABEL \\ HERE
}

Name $\ldots \ldots \ldots \ldots \ldots \ldots \ldots \ldots \ldots \ldots$
New Address $\ldots \ldots \ldots \ldots \ldots \ldots \ldots$
City $\ldots \ldots \ldots \ldots \ldots \ldots \ldots \ldots$
State $\ldots \ldots \ldots \ldots \ldots \ldots$ 